\title{
覆砂材投入に伴い発生する懸濁物質等に及ぼす 密度躍層の影響
}

\author{
斉藤 直 1 - 桑原 智之 2 ・相崎 守弘 3 \\ 1正会員 中国電力株式会社 電源事業本部（干730-8701 広島市中区小町4-33） \\ E-mail:355606@pnet.energia.co.jp \\ 2島根大学准教授 生物資源科学科（广690-8504 島根県松江市西川津町1060） \\ E-mail: kuwabara@life.shimane-u.ac.jp \\ 3 島根大学名誉教授（干690-0064 島根県松江市天神町114） \\ E-mail: aizakim7@gmail.com
}

\begin{abstract}
覆砂等の工事では, 懸濁物質の発生を伴い, 濁りによる周辺環境への影響を予測評価し, 更には管理し ながら進めていく必要がある。このような工事は，水温や塩分による密度成層が生じやすい閉鎖性の港湾 や水域等で実施されることが多く, 水底付近で発生する濁りの拡散挙動が密度成層の状態により変化する ため, その挙動に沿った濁り対策を講じることが求められる.

本稿は, 汽水域での覆砂工事において, 密度躍層の状態による懸濁物質の挙動への影響評価を試みたも のである. 特異な $\mathrm{C} / \mathrm{N}$ 覆砂材を使用し, 発生する懸濁物質を投入材料の細粒分の影響と水底粘土の巻き 上がりの影響とに分けて懸濁物質の挙動評価を試みた結果, 懸濁物質の $80 \%$ 以上が湖底粘土に起因してお り，密度躍層境界を通過して上層まで拡散する䀣濁物質の主要因であることが示された。
\end{abstract}

Key Words : suspended solid, density stratification, carbon to nitorogen ratio, granulated coal ash

\section{1. 背 景}

港湾事業など海域で実施される浚渫事業や覆砂事業に おいては，懸濁物質（SS）等の濁りによる周辺環境へ の影響を考慮しながら事業を進める必要があり，污濁防 止枠や污濁防止膜などの環境対策を図った上で，工事が 進められている. 特に，大規模な事業においては，工事 に伴う濁りによる影響評価 ${ }^{1)}$ を行ったうえで，周辺海域 への影響についてモニタリングの実施や，水質監視シス テムの運用 ${ }^{2)}$ など，周辺環境へ配慮しながら事業を進め ていくこととなる. 一方で，これらの事業や工事の多く が実施される港湾区域内の泊地・航路等では，港湾周辺 の工場等からの温排水などの影響のほか，防波堤等の外 郭施設による港湾の閉鎖性によって水交換性の低下が生 じていること等から，水温等に起因した密度躍層を持つ 水域となっている場合も多い。このような密度躍層を有 する水域で, 濁りの発生する事業や工事が多く実施され ている現状にあり，更に近年では，閉鎖性水域における 水底泥からの内部負荷（硫化水素や栄養塩等）の抑制な ど環境修復を目的とした覆砂事業 ${ }^{3,4,5)}$ も行われるに至っ ており, 水温や塩分にも起因した強い密度躍層が発達し た水域での事業も対象となりつつある.
このように, 密度躍層が存在する水域で実施される事 業や工事においては，水域の特性に応じた懸濁物質の拡 散特性を踏まえた防止対策を講じていく必要がある.こ れまで, 密度躍層を持つ水域での懸濁物質の拡散挙動に ついて，既往の土砂投入実験による研究において微小 な密度差が濁りの鉛直拡散影響を及ぼすことが報告 ${ }^{3)}$ され，投入土砂の模型実験で密度成層の状態が濁りの鉛 直拡散に影響を及ぼす $\left.{ }^{6}\right)$ など，定性的な知見はあるもの の定量的な解明まではなされていないのが現状である.

本報では，密度躍層を持つ汽水湖における大規模な覆 砂を通じて，覆砂投入時に発生する懸濁物質量と湖水の 密度の鉛直分布の関係から密度躍層の強さやその状態に 応じた懸濁物質の拡散挙動の変化を把握すると共に, 発 生する矁濁物質の要因について考察を行った.

\section{2. 投入材料の選定}

\section{(1) 投入材料の特性}

矁濁物質の発生は，覆砂工事の投入材料による影響と 水底に存在する在来粘土の巻き上がりによる影響が複合 したものである.これらに起因するそれぞれの懸濁物質 の発生が，密度躍層を介してどのような挙動特性を持っ 
表-1 投入材料と在来水底土の特性

\begin{tabular}{|c|c|c|c|c|c|c|c|c|}
\hline \multirow[b]{2}{*}{ Material } & \multicolumn{2}{|c|}{ Physical Properties } & \multicolumn{3}{|c|}{ Grain Size $(\mathrm{mm})$} & \multicolumn{3}{|c|}{ Chemical Elements } \\
\hline & $\begin{array}{c}\text { Wet Density } \\
\left(\mathrm{g} \cdot \mathrm{cm}^{-3}\right) \\
\end{array}$ & $\begin{array}{c}\text { Water Content } \\
(\%)\end{array}$ & $>2$ & $>0.064$ & $0.064>$ & $\begin{array}{c}\text { Carbon } \\
(\%) \\
\end{array}$ & $\begin{array}{c}\begin{array}{c}\text { Nitrogen } \\
(\%)\end{array} \\
\end{array}$ & $\mathrm{C} / \mathrm{N}$ \\
\hline Sand & 1.820 & - & $31.2 \%$ & $51.7 \%$ & $17.1 \%$ & 0.52 & 0.000 & - \\
\hline Gravel & 1.925 & - & $100 \%$ & \multicolumn{2}{|c|}{-} & - & - & - \\
\hline GCA & 1.269 & - & $93.4 \%$ & $0.4 \%$ & $6.1 \%$ & 2.78 & 0.029 & 95.9 \\
\hline Bottom Clay & 1.260 & 61.9 & - & \multicolumn{2}{|c|}{$100 \%$} & 10.90 & 2.427 & 4.5 \\
\hline
\end{tabular}

ているのかを把握して評価するためには，投入材料の選 定とその挙動特性の把握が必要となる.

投入材料に起因寸る䀣濁物質と在来水底粘土に起因寸 る懸濁物質とを区分して評価するためには，それぞれの 懸濁物質の材料特性に何らかの顕著な差異がある必要が ある. 表-1には，投入材料として考えられた材料と在 来の水底粘土について, 室内試験で得られた特性を示し ている. 表中の水底粘土の特性值は実証を行った場所の 水底に堆積した粘土の值であり, その表面には水底粘土 と同じ化学組成を持つが高含水比 $(\omega 0>200 \%)$ のフロ ック化した浮泥状の粒子も存在している. 投入材料の選 択に当たっては，一般的に覆砂に使用される山砂（Sand） のほか，山砂と素材が同一で粒径の大きい $\mathrm{D}=40 \mathrm{~mm}$ の 単粒砕石（Gravel）, 山砂と砕石の中間粒径（D=3〜 40mm）で軽量の石炭灰造粒物（GCA）の3種類を使用し た。これらの材料の CN 比を見ると，石炭灰造粒物は $\mathrm{C} N \mathrm{~N}=95.9$ と高く, 水底粘土の $\mathrm{C} N=4.5$ と比較して大きな 差異が認められ，石炭灰造粒物は投入材料と水底粘土の それぞれに起因する懸濁物質の成分を区分する目的に適 った材料と考えられる.

\section{(2) 小規模投入実験}

これらの材料投入時の懸濁物質を評価するため，現地 実証に先だって，小規模な現地投入実験によって巨視的 な挙動把握を行った．現場投入実験は，密度躍層を持つ 汽水湖（中海）において，表-1 に示寸各材料をそれぞ れ $1 \mathrm{~m}^{3}$ ずつ水面から投入し，懸濁物質量の測定を行った。 対象の汽水湖の密度躍層は, 数日ごとに変化するため, 投入開始時に水温・塩分測定を行い，投入時点の湖水の 密度成層を把握すると共に，密度の鉛直分布を調査した。 懸濁物質量の測定は，図-1 に示すセジメントトラップ （水深 $1 \mathrm{~m}$ 間隔に設置）を投入位置を中心にして周辺に 3カ所配置して, そのトラップ量から各水深の懸濁物質 量を求めた.

図-2 に，投入時点の塩分濃度と懸濁物質量の鉛直分 布を示す．いずれの材料も，密度躍層境界の直下で最大 の䀣濁物質量となっており，主に下層で発生した懸濁物 質が密度躍層によって上層へ拡散しにくい状況となって, 下層内で沈下していく傾向となることが分かる．密度躍

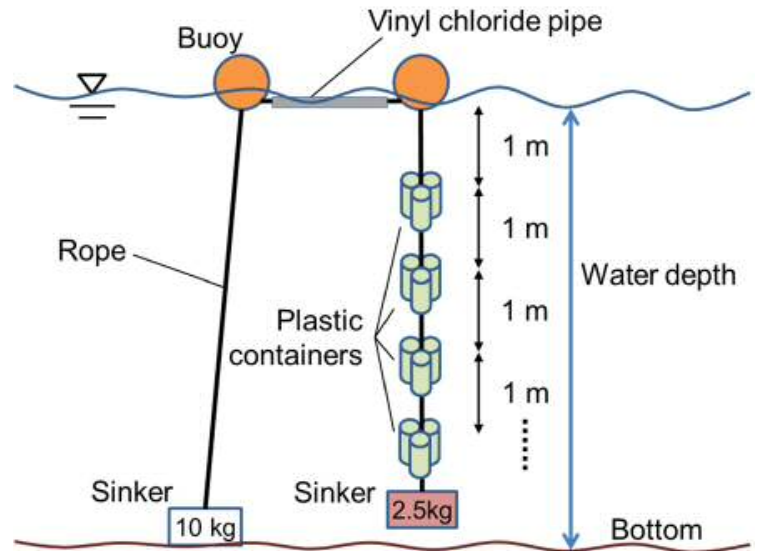

図-1 セジメントトラップ設置概要図

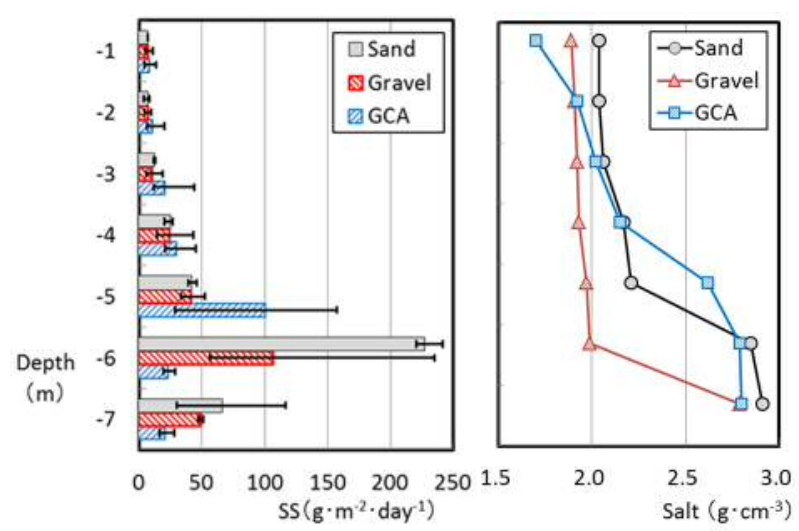

図-2 懸濁物質量と塩分濃度の鉛直分布

層境界は，材料投入の伴う水圧の渦動等によっても破壊 される可能性も考えられたが，材料投入程度の変動影響 では破壞まで至っていないものと考えられ，発生した懸 濁物質の鉛直方向の拡散が密度躍層境界によって支配さ れている.

䀣濁物質量を見ると，粒子密度が大きく細粒の山砂は， 粒径の大きい砕石や石炭灰造粒物と対比して, 懸濁物質 量が約 2 倍程度大きくなっている. 既往の研究6)では, 粒子沈降に伴い発生する浮力が濁り拡散の要因であるこ とが報告されており，粒子重量（沈降速度）や粒径（間 隙）の相違による水圧変動の差が懸濁物質量の差につな がっているものと推定される.

これらの一連の結果から, 発生する懸濁物質量は一般 
的な山砂より少ないものの，䀣濁物質の鉛直方向への密 度躍層を介しての分布の傾向については，どの材料も密 度躍層の影響をみれば大差がなく，覆砂材投入時の䀣濁 物質を CN 比によって投入材料による影響と水底泥の巻 きがりによる影響とに区分して定量的に評価ができるこ とから，石炭灰造粒物を実証の材料として選定した。

\section{3. 大規模実証試験工事による評価}

\section{(1) 実証試験条件及び方法}

大規模実証試験は，中海の細井沖に存在する独立性窪 地への覆砂工事を対象とした。細井沖の独立性䆶地は, 図-3に示寸ように WL.-3〜-4m の在来湖底を WL.-7〜 - $8 \mathrm{~m}$ 程度まで浚渫された窪地であり, 窪地内の水流が在来湖 底以深ではほとんどない状態となっている。

実証試験は，密度躍層条件の変化を期待して，春季と 冬季の 2 季節に分けて，それぞれ複数回の観測を行った. 表-2 には各季節の実証条件を示寸が，污濁防止枠によ り在来湖底以深に防止膜を設置した条件で，グラブ船に よる材料の投入を行い，投入場所から春季が $50 \mathrm{~m}$ ，冬季 が 100m 離れた洼地内の場所に図-1 と同様なセジメント トラップを設置して，水深毎に沈降した縣濁物質量の測 定を行った．合わせて，各測定期間における湖水の密度 の分布や躍層の状態を評価するために, 水温及び塩分濃
表-2 投入材料と在来水底土の特性

\begin{tabular}{l|c|c}
\hline \multicolumn{1}{c|}{ Item } & Spring & Winter \\
\hline Area of Sand-Capping & $1,600 \mathrm{~m}^{2}$ & $32,400 \mathrm{~m}^{2}$ \\
\hline Depth of Silt Screen & WL.-7m & WL.-5m \\
\hline Distance of SS-Trap & $50 \mathrm{~m}$ & $100 \mathrm{~m}$ \\
\hline Number of SS-Trap & 3 & 1 \\
\hline
\end{tabular}

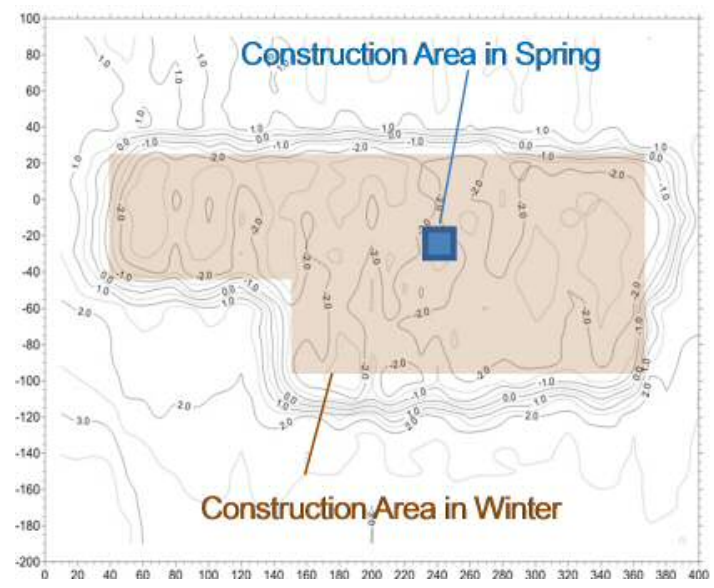

図-3 実証試験を行った浚渫窪地と材料投入エリア

度の測定を行った. セジメントトラップで採取した懸濁 物質は，䀣濁物質の発生要因（材料）を特定するために, 懸濁物質に含有する炭素（C）と窒素（N）の同定を行 った.
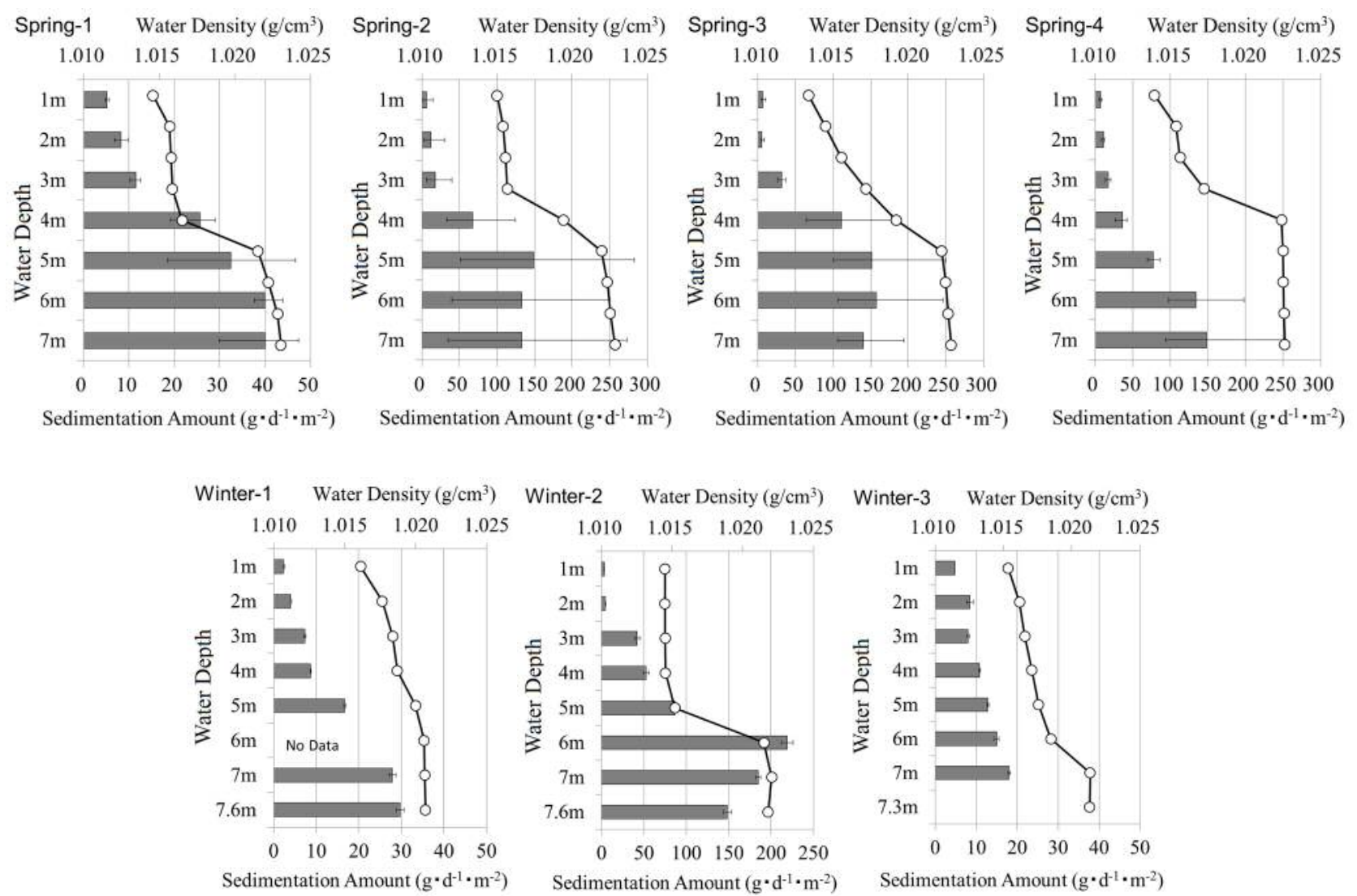

図-4 測定全期間の懸濁物質と湖水密度の鉛直分布 


\section{(2) 観測結果の概要}

図-4 は，セジメントトラップで捕捉した懸濁物質量 に合わせて，湖水の密度の観測結果を鉛直分布として図 示したものである．図中の湖水の密度は，深度別に測定 した湖水の塩分濃度と水温を基に，下式 (1) に示寸国際 海水状態方程式 (1980) ${ }^{77}$ によって算定した值である.

$$
\begin{gathered}
\rho(S, T, 0)=\rho_{\mathrm{w}}+B(T) \cdot \mathrm{S}+C(T) \cdot S^{3 / 2}+d_{0} \cdot S^{2} \\
{\left[\begin{array}{l}
\rho_{\mathrm{w}}=a_{0}+a_{1} T+a_{2} T^{2}+a_{3} T^{3}+a_{4} T^{4}+a_{5} T^{5} \\
B(T)=b_{0}+b_{1} T+b_{2} T^{2}+b_{3} T^{3}+b_{4} T^{4} \\
C(T)=c_{0}+c_{1} T+c_{2} T^{2}
\end{array}\right.}
\end{gathered}
$$

ここに, $\rho(S, T, 0) ; 1$ 気圧下の海水密度 $\left(\mathrm{kg} / \mathrm{m}^{3}\right)$,

$\rho_{\mathrm{w}}$;淡水の密度, $B(T), C(T)$; 水温補正項,

$S$; 実用塩分 $(\mathrm{psu}), T$; 水温 $\left({ }^{\circ} \mathrm{C}\right)$,

$a_{0} \sim a_{5}, b_{0} \sim b_{4}, c_{0} \sim c_{2}, d_{0} ;$ 定数 ${ }^{7)}$

観測期間を通じて，懸濁物質量にはバラツキはあるも のの，懸濁物質の鉛直分布形状は，湖水の密度分布と大 きな関係性が見られる，湖水の密度が高い下層では，懸 濁物質量の濃縮が見られ，密度が小さくなる上層では懸 濁物質が拡散しにくく，䀣濁物質量は上層で低い值とな ることが分かる.

\section{(3) 密度躍層の状態と懸濁物質量の関係}

図-5に，各材料投入時における湖水の密度の鉛直分 布を示寸，対象地点における湖水密度の鉛直分布は，季 節には大きく関係せず，密度躍層の形成と消失を繰り返 している．明確な密度躍層が見られるのは，Spring-1，4 及び Winter-2 であるが，躍層境界はその時期によって変 化するものの，在来湖底のレベルと比較して，概ね下層 に高い密度層が位置していることが分かる。

このように，投入時期によって密度躍層の強弱や厚さ は変化しており，それぞれの密度躍層の状態と懸濁物質 量の関係を見れば，密度躍層の状態による懸濁物質の状 態を評価できるものと推察される．図-6に，湖水の密 度と懸濁物質の総量の関係を示す。この図は，図-5に 示した密度の鉛直分布の形態によって，投入時期別に下 層・中層・上層の範囲を区分して，その区間の平均值で 湖水密度と縣濁物質総量を示したもので，懸濁物質総量 と湖水密度の関係は，巨視的に見て強い正の相関関係に あることが分かる。

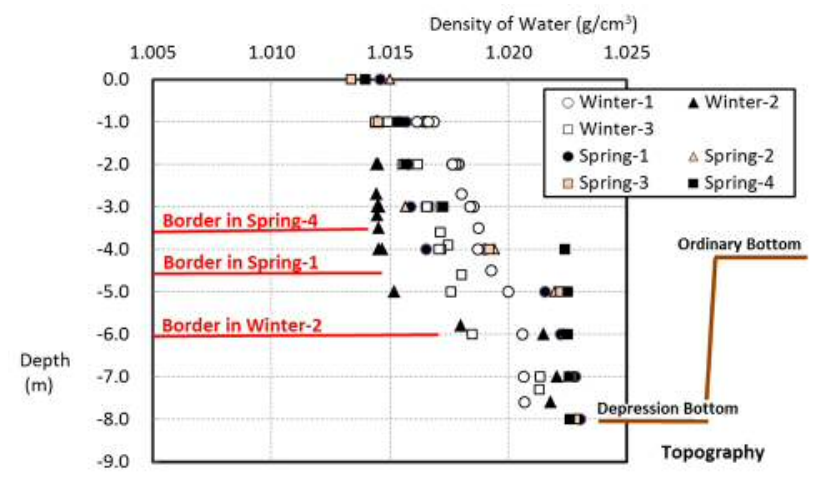

図-5 各材料投入時の湖水密度の鉛直分布

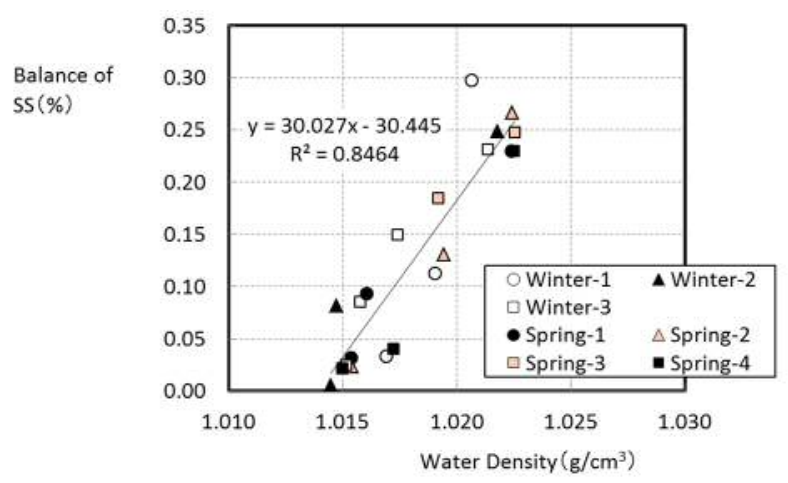

図-6 湖水密度と懸濁物質総量の関係

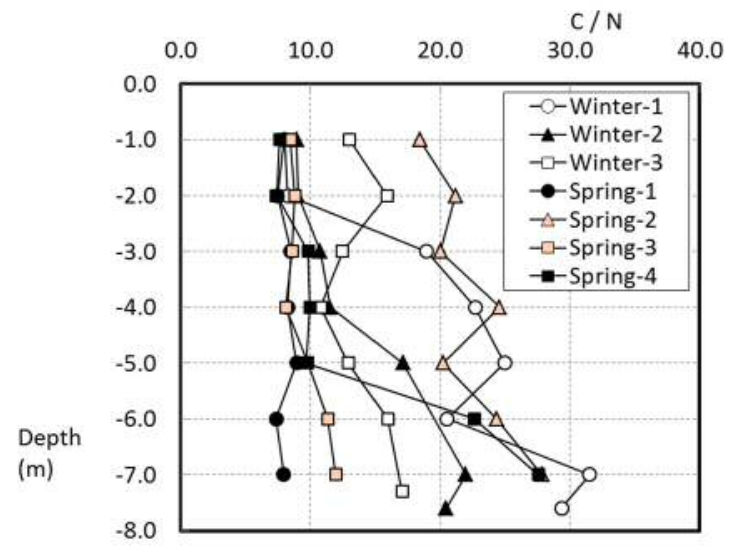

図-7 回収した懸濁物質のCN $の$ 鉛直分布

\section{（4）懸濁物質量に起因する材料要因}

懸濁物質等の濁りの発生要因は，材料投入時における 投入材料の細粒分によるものと材料着底時の水圧変動に よって巻き上がる湖底粘土によるものが考えられ，これ ら2つの材料要因が複合して懸濁物質量が構成されるも のと考えられる. 前述したとおり，投入材料の石炭灰造 粒物と在来の湖底粘土のそれぞれ異なる $\mathrm{CN}$ によって, この材料要因を明らかにすることを試みた。

図-7 に，セジメントトラップで回収した懸濁物質の $\mathrm{C} / \mathrm{N}$ を示す． $\mathrm{C} / \mathrm{N}$ の鉛直分布は，投入時期によって大き く異なっていることが分かる．CAN が表層まで高い水準 となっているのは，上下層の湖水の密度差が小さい時期 のものであり，強い密度躍層境界が見られる時期におい ては，高い C $\mathrm{N}$ となる領域が下層に限定されていること 

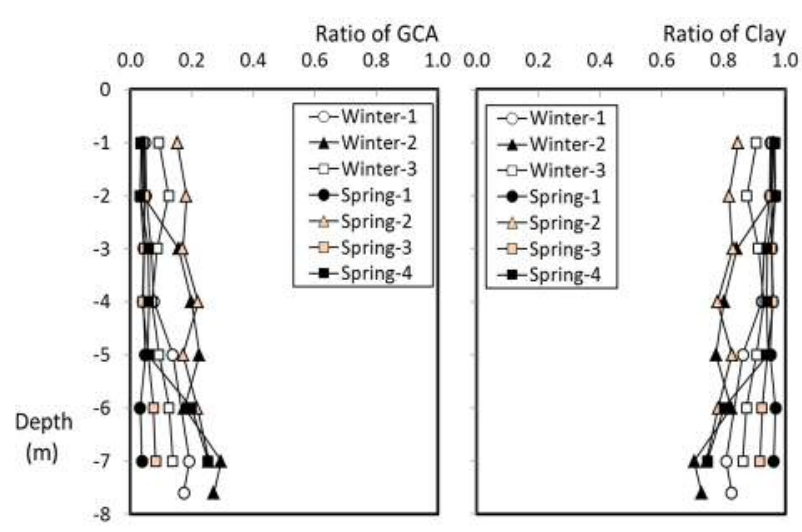

図-8 CNによる発生要因となる材料比率の分布

が分かる．このように，密度躍層境界が明確な場合には， 投入材料によって生じる䀣濁物質は, 躍層境界より下層 に限定される傾向が強くなる.

図-8に, CN によって発生原因となる材料の比率を求 め, その比率の鉛直分布を示す. 材料比率を鉛直分布で 見れば，在来の湖底粘土（Clay）に起因寸る懸濁物質の 比率は約 80\%（70９5\%） と高く，投入材料（GCA）に 起因する懸濁物質の比率は約 20\%（5３0\%）程度で, 材料投入に伴う懸濁物質は湖底粘土の巻き上がりよって 支配されていることが明らかとなった．鉛直分布形状を 見ると，投入材料に起因寸る懸濁物質は，上層に向かっ て一定の低減傾向を示し, 低減傾向が少ないものは材料 投入位置と観測位置が $50 \mathrm{~m}$ と近い春季（Spring-2，4）の もので, 密度躍層境界も比較的浅い位置にあるものであ る. 鉛直分布から見れば，上層まで影響を及ぼす賏濁物 質は, 湖底粘土に起因するものが多く, 投入材料に起因 する懸濁物質の比率は低下寸る傾向を示していることが 窥える.

懸濁物質の鉛直分布は，図-8 に示した起因する材料 比率に懸濁物質量を乗じたものとなる。図-9には，投 入時の表層から下層までの懸濁物質総量に対寸る各深度

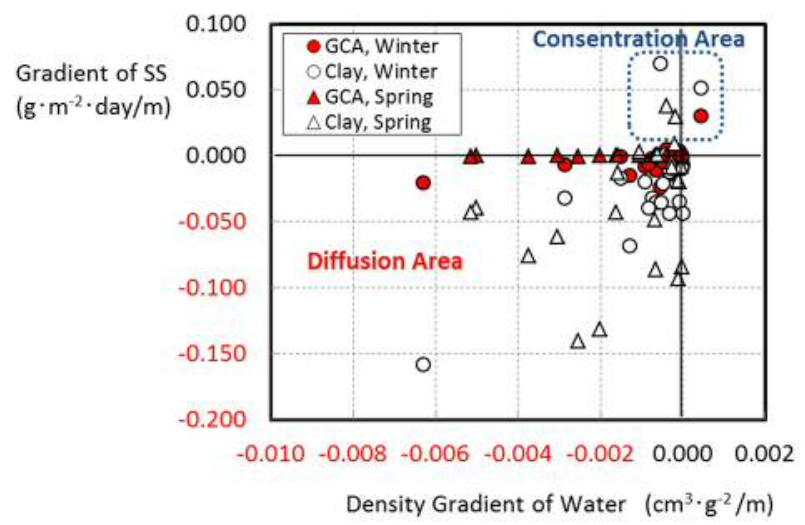

図-10 湖水の密度勾配とSS変化量の関係

の懸濁物質の比率で示した．それぞれ，䀣濁物質総量の 鉛直分布比率（Ratio of Toal SS），懸濁物質総量に対する 投入材料及び湖底粘土に起因する懸濁物質量の鉛直分布 比率（Ratio of GCA，Clay） で示している. 材料投入によ って発生する懸濁物質は, その大半が湖底粘土に起因寸 る懸濁物質であり，投入材料の細粒分に起因して発生す る懸濁物質は非常に少ない，また，密度躍層境界を通過 して上層まで拡散した懸濁物質は，その大半が湖底粘土 によるものであることが分かる.

湖水の密度勾配と水深 $1 \mathrm{~m}$ 当りの懸濁物質の変化量の 関係を図-10 に示寸，懸濁物質は，その起因物質によら す，躍層境界より下層で懸濁物質の濃縮が生じ，上層に 向かって濃度が低下寸る. 投入材料に起因する懸濁物質 は，その絶対量は小さく，鉛直方向に概ね一定の減少傾 向を示す，一方で，湖底粘土の巻き上がりによる懸濁物 質は，その絶対量が大きく，湖水の密度勾配によって低 減する傾向を示しており，材料投入箇所に近い春季

(Spring) で低減量のバラツキが大きくなる.

これらのことから, 密度躍層を有寸る水域においては, 污濁防止膜を躍層界面付近まで設置すれば投入材料によ る濁りを躍層境界より下層に封じ込む有効な対策となる
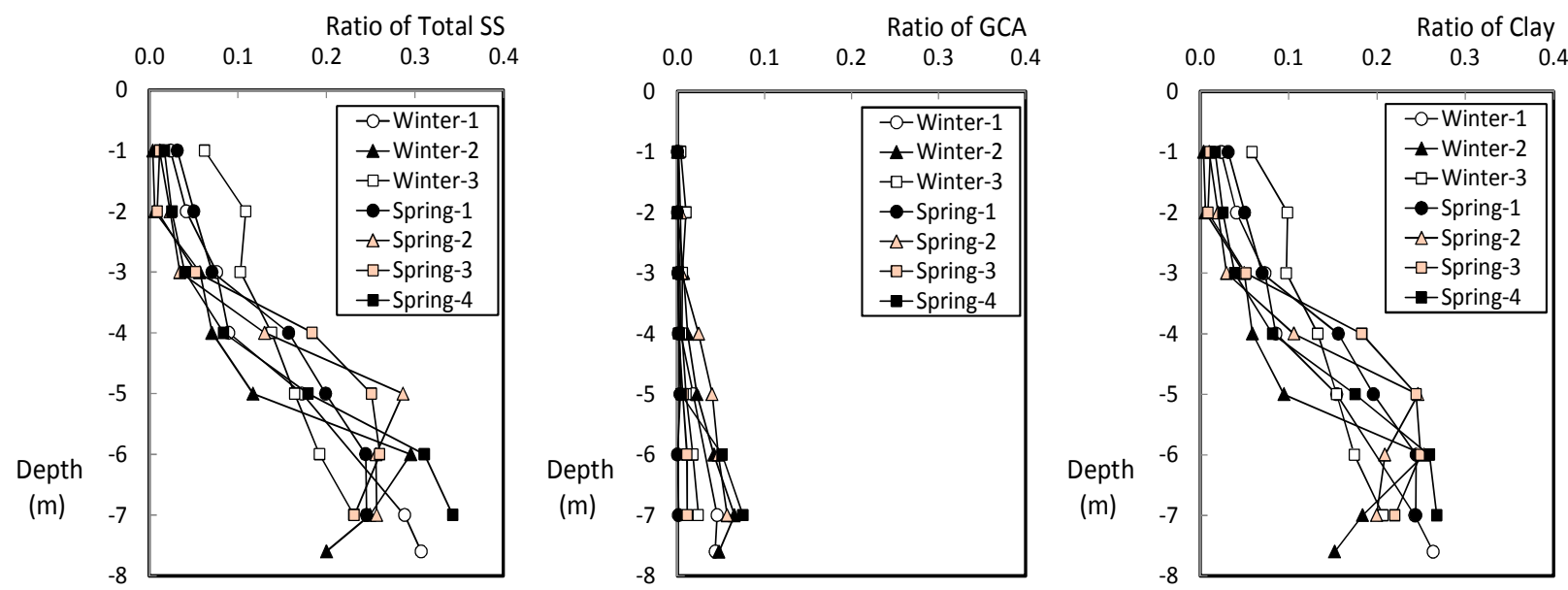

図-9 測定全期間の懸濁物質と湖水密度の鉛直分布 
が，矁濁物質の大半を占める湖底粘土の巻き上がりによ る濁りに対しては，材料の投入方法も含めた対策検討が 必要と考えられる.

表-1 に示したように，土粒子密度は投入材料と湖底 粘土で顕著な差異はないが，湖底粘土で細粒分の含有量 が非常に大きい，また，湖底には写真-1 に示寸ような フロック化した細粒分が大量に存在しているため, この フロック化して圧密していない見かけ上の密度が小さい 細粒分の巻き上がりも一つの大きな賏濁物質量に影響を 及ぼす要因と考えられる．このように，䀣濁物質の挙動 の差異は, 懸濁物質の量と形態に影響を受けるものと考 えられる。

\section{4. 結 論}

本検討により得られた，覆砂材投入に伴い発生する懸 濁物質等に及ぼす密度躍層の影響の結論は以下の通りで ある。

○密度躍層境界面によって, 境界面より下層で懸濁 物質の濃縮が生じ, 躍層境界より上層へ拡散しに くい状態となる，巨視的に見ると，各密度成層の 湖水密度と䀣濁物質量は相関関係にある。

○CNによって懸濁物質成分を覆砂材と在来粘土に区 分した結果, 在来粘土の巻き上がりによる懸濁物 質が大半を占める．密度躍層境界を通過して上層 まで拡散する懸濁物質は，在来粘土による懸濁物 質が主要因となる.

○投入材料に起因寸る懸濁物質は，概ね上層に向か って一定勾配で濃度が低下寸るが, 密度躍層境界 が明確な場合は躍層境界よりも下層に限定される。 在来粘土の巻き上がりに起因寸る懸濁物質は, 湖 水の密度勾配による懸濁物質量の変化量が大きく, 投入場所近傍ではバラツキが生じる.

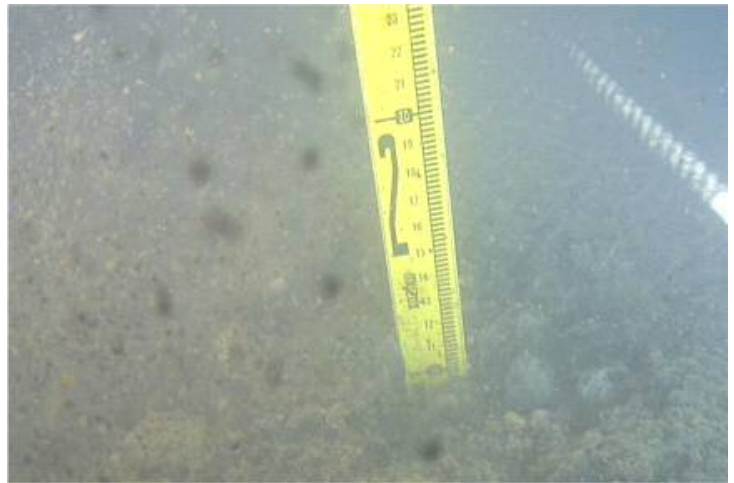

写真-1 湖底表面に存在するフロック化した浮泥

\section{参考文献}

1) 環境影響評価法 : 法律第 81 号, 2009.

2) 白石修章, 伊藤弘樹, 小山善明, 天水太一：関西国 際空港における土運船等による濁りの発生量の定量 把握, 海岸工学論文集, Vol.47, pp. 1271-1274, 2000.

3) 堀江 穀, 井上聴史, 村上和男, 細川恭史 : 三河湾 での覆砂による底質上下の環境に及ぼす効果の現地 実験，土木学会論文集，No.533，II-34，pp.225-235， 1996.

4) 内藤了二, 井上徹教, 中村由行, 浦瀬太郎, 久野賢 二：三河湾窪地の埋め戻し土砂投入時における濁り の拡散特性と密度成層の効果, 海岸工学論文集, Vol.55, pp.1251-1255, 2008.

5) 斉藤 直, 桑原智之, 相崎守弘, 徳岡隆夫 : 自然再 生推進法に基づく中海自然再生事業, 土木学会論文 集 B3（海洋開発），Vol.70, No.2, pp.I_1128-I_1133, 2014.

6) 武田将英, 松澤圭祐, 佐々木淳, 津田宗男, 松田信 彦：成層水域における下層への土砂投入に伴う濁り の拡散特性, 土木学会論文集 B2 (海岸工学), Vol. 66, No.1, pp.946-950, 2010.

7) 日本海洋データセンター：実用塩分と国際海水状態 方程式（改訂版）, pp.11-12, 1984.

(2015.3.18 受付)

\title{
INFLUENCE OF DENSITY STRATIFICATION OF WATER FOR PERFORMANCE OF SUSPENDED SOLID BY CASTING COVERING MATERIAL
}

\author{
Tadashi SAITO, Tomoyuki KUWABARA and Morihiro AIZAKI
}

Sand capping works are often used in the closed water area with density stratifications of water. In the case of sand capping works, behavior of suspended solid "SS" is changed according to the condition of density stratifications of water. It is necessary to reflect the condition of the density stratification of the water to take the measures of the diffusion prevention of SS.

In this paper, relation of SS behavior and density stratification was evaluated using sediment trap when the sand capping construction was conducted at the brackish lagoon. Collected SS by sediment trap could be classified by fine grain on material and ordinary clay rolling up from the bottom by measuring the $\mathrm{C} / \mathrm{N}$ ratio of SS, because granulated coal ash has the characteristic of high $\mathrm{C} / \mathrm{N}$ ratio. In consequence, it was shown that $80 \%$ of SS gross weight was based on SS of ordinary clay, and most of SS which was diffused from bottom to upper area through the border of density stratification was caused by ordinary clay. 